\title{
Prognostic importance of pentraxin 3 levels in acute cholesistitis
}

\author{
Nurhak Aksungur, M.D., ${ }^{1}$ Bünyami Özoğul, M.D., ${ }^{1}$ Nurunnisa Öztürk, M.D., ${ }^{2}$ \\ Şükrü Arslan, M.D., ${ }^{1}$ Erdem Karadeniz, M.D., ${ }^{1}$ Ercan Korkut, M.D., ${ }^{1}$ \\ Mehmet Ali Gül, M.D., ${ }^{2}$ Abdullah Kısaoğlu, M.D., ${ }^{1}$ Sabri Selçuk Atamanalp, M.D. ${ }^{1}$
}

${ }^{1}$ Department of General Surgery, Atatürk University Faculty of Medicine, Erzurum

${ }^{2}$ Department of Biochemistry, Atatürk University Faculty of Medicine, Erzurum

\begin{abstract}
BACKGROUND: Cholelithiasis is a frequently encountered problem in developed countries. Gallstone is present in at least $10 \%$ of the adults. While $40-60 \%$ of people with gallstones manifest an asymptomatic clinical course, in most of the cases with symptomatic cholelithiasis, there is also an asymptomatic period. $20 \%$ of the patients with symptomatic gallstones are admitted to emergency services with clinical features of acute cholecystitis. In this study, our aim was to evaluate the diagnostic value of pentraxin 3 on complications and prognosis and also to reduce the morbidity and mortality rates in cases with acute cholecystitis.
\end{abstract}

METHODS: This study was conducted on patients diagnosed with acute calculous cholecystitis and operated on between September 2012 and January 2014, in the Department of General Surgery of Atatürk University Medical Faculty. Forty-five patients with ages above 18, who were clinically and radiologically diagnosed with acute calculous cholecystitis (Group I) and 45 healthy people, older than 18 (Group II) were included into the study. Patients were randomly selected.

RESULTS: In our study, although the plasma pentraxin 3 (PTX3) levels were increased in the patient group and also in patients who developed morbidity, this was not statistically significant. PTX3 values were determined to be significantly increased in older patients $(p<0.05)$. Moreover, when the duration of hospital stays were compared, PTX3 was found to be significantly higher in patients hospitalized for longer periods $(p<0.05)$.

CONCLUSION: PTX3 levels were found to be elevated in all evaluated parameters in patients with acute cholecystitis. Therefore, PTX3 level may be a valuable indicator in diagnosis and also in predicting prognosis.

Keywords: Acute cholecystitis; morbidity; mortality; pentraxin 3.

\section{INTRODUCTION}

Cholelithiasis is one of the most frequently encountered disorders affecting the gastrointestinal system. While gallstone is the cause in $95 \%$ of the cases with acute cholecystitis, in $2-15 \%$ of the cases, acute acalculous cholecystitis may occur. [1] Acute acalculous cholecystitis may be diagnosed in conditions such as severe trauma, major surgery, advanced age,

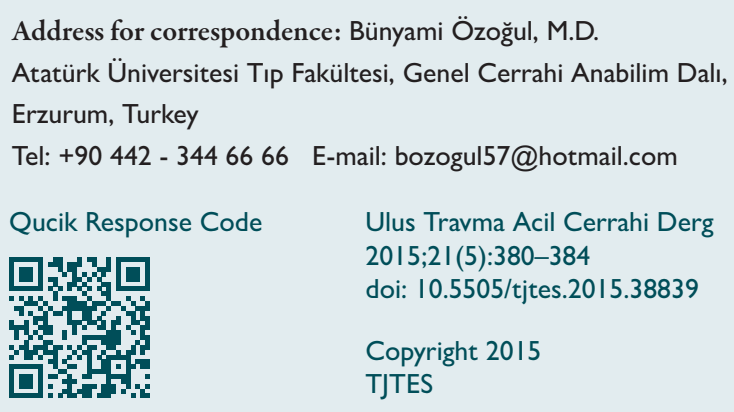

diabetes mellitus, immunosuppression, and total parenteral nutrition. ${ }^{[2]}$

Pentraxin 3 (PTX3) is a member of the pentraxin family, also named as tumor necrosis factor (TNF) -inducible gene 14 protein (TSGF 14). ${ }^{[3]}$ PTX3 is released from macrophages and other various cell types as a result of their stimulation by primary inflammatory mediators such as lipopolysaccharide, interleukin-I, and tumor necrosis factor alpha (TNF $\alpha$ ). ${ }^{[4]}$ The plasma level of PTX3 is fairly low $(2 \mathrm{ng} / \mathrm{ml})$. In recent years, it has been determined that its level is increased during systemic inflammatory conditions. However, in search of the medical literature, no study has been found about the place of PTX3 as an inflammatory marker in patients with acute cholecystitis.

In this study, it was aimed to evaluate the diagnostic value of PTX3 on complications and prognosis and also to reduce morbidity and mortality rates in patients with acute cholecys- 
titis, who may develop serious complications such as empyema, gangrene and perforation.

\section{MATERIALS AND METHODS}

This study was conducted on patients diagnosed with acute cholecystitis and operated on between September 2012 and January 2014, in the Department of General Surgery of Atatürk University Medical Faculty. Subjects included into the study were divided into two groups consisting of forty-five people. Patients were randomly selected.

Group I (Acute cholecystitis group): Patients diagnosed with acute calculous cholecystitis by their medical history, clinical features and ultrasonographic examinations were included into this group. Patients who had other inflammatory diseases were excluded.

Group II (Control group): It consisted of healthy people, who had no history of inflammatory diseases and who were clinically normal by medical history and physical examination, at the time they were included into the study.

\section{Biochemical Analysis}

Venous blood samples taken from the patient group and control group into hemogram test tubes containing EDTA were centrifuged at $3000 \mathrm{rpm}$ for 10 minutes, and then, they were stored at $-80^{\circ} \mathrm{C}$ until the day that the analysis was performed. Plasma levels of pentraxin 3 were measured by Human Pentraxin 3 ELISA kit (Hycult Biotech, Netherlands) using a microplate reader (Bio-Tek Power Wave XS). Tests for AST, ALT, GGT, LDH and bilirubin were made by spectrophotometric method using Beckman Coulter AU5800 (Beckman Coulter Inc., BreacA, USA) autoanalyzer. WBC and PLT were measured by Coulter LH 780 Hematology Analyzer (Beckman Coulter Inc.).

\section{Statistical Analysis}

Statistical analysis was performed using SPSS 20.0 statistical analysis program (SPSS Inc, Chicago, USA). Results were calculated as mean \pm standard deviation (SD). Conformity of the parameters to the normal distribution was assessed by Kolmogorov-Smirnov test. Independent t-test, one of the parametric tests, was used for comparison of parameters with normal distribution. Statistical evaluation of data which did not meet the normal distribution was performed using the Mann-Whitney $U$ test.

\section{RESULTS}

In Group I, twenty-two patients (49\%) were males and twenty-three (5I\%) were females. In Group II, twenty-five patients (53\%) were males and twenty (47\%) were females. When PTX3 levels were compared between genders of the subjects in Groups I and II, no statistically significant difference was found. The results are given in Table I.

When age-related data of the subjects were analyzed, in Group I, mean age was $58.7 \pm 20$ years (19-86), and in Group II, mean age was $54 \pm 40$ years $(21-74)$. PTX3 values were detected to be significantly increased with age $(p<0.05)$. Leukocyte (WBC), platelet (PLT), lactate dehydrogenase (LDH), aspartate aminotransferase (AST), alanine aminotransferase (ALT), gamma glutamyl transferase (GGT), total bilirubin, and direct bilirubin levels of the patients included into the study were measured. These results are given in Table 2 .

Patients were compared in terms of duration of hospitalization. Mean duration of hospitalization was determined as seven days when the total of 45 patients was taken into consideration. PTX3 level of the patients with a duration of hospitalization longer than seven days was found to be significantly higher when compared to that of the patients hospitalized less than seven days $(p<0.05)$.

In our study, patients who underwent cholecystectomy were compared in terms of gangrene development in the gallbladder. While the gallbladder was gangrenous in eight patients who underwent cholecystectomy, in eighteen patients, gross appearance of acute cholecystitis was present. No statistically significant difference was found between PTX3 levels of the two groups. The results are given in Table 3 .

The morbidity and mortality rates of the patients were compared. There were various lung disorders in seventeen patients. Nine patients developed wound complications. In two patients, both lung and wound complications developed. Although PTX3 levels were higher in patients who developed morbidity, there was no statistically significant difference.

Table I. Difference of PTX3 levels between the female and male genders

\begin{tabular}{|c|c|c|c|c|c|}
\hline & $\begin{array}{l}\text { Female patient } \\
\qquad(n=23)\end{array}$ & $\begin{array}{l}\text { Female control } \\
\qquad(n=20)\end{array}$ & $\begin{array}{l}\text { Male patient } \\
\quad(n=22)\end{array}$ & $\begin{array}{l}\text { Male control } \\
\quad(n=25)\end{array}$ & $\mathbf{p}$ \\
\hline & Mean \pm SD & Mean \pm SD & Mean $\pm S D$ & Mean \pm SD & \\
\hline Pentraxin 3 (ng/ml) & $24 \pm 10.5$ & $12.65 \pm 4.54$ & $23.49 \pm 10.25$ & $13.39 \pm 4.49$ & $>0.05$ \\
\hline
\end{tabular}


Table 2. WBC, PLT, LDH, PTX3, AST, ALT, GGT and bilirubin values in patient and control groups

\begin{tabular}{|c|c|c|c|c|c|}
\hline & Patient group $(n=45)$ & Control group $(n=45)$ & Patient group $(n=45)$ & Control group $(n=45)$ & $\mathbf{p}$ \\
\hline & Mean $\pm S D$ & Mean $\pm S D$ & Min-Max & Min-Max & \\
\hline Age & $58.7 \pm 20$ & $54 \pm 4$ & - & - & $0.04 I^{*}$ \\
\hline PTX3 (ng/ml) & $23.75 \pm 10.26$ & $13.07 \pm 4.48$ & - & - & $0.000^{*}$ \\
\hline WBC $\left(10^{3} / \mu \mathrm{L}\right)$ & $12900 \pm 5800$ & $7000 \pm 1600$ & - & - & $0.000^{*}$ \\
\hline $\operatorname{PLT}\left(10^{3} / \mu \mathrm{L}\right)$ & $230000 \pm 6000$ & $270000 \pm 7000$ & - & - & $0.000^{*}$ \\
\hline LDH (U/L) & $300 \pm 114$ & $195 \pm 64$ & - & - & $0.000^{*}$ \\
\hline AST (U/L) & - & - & $12-460$ & $10-36$ & $0.000^{*}$ \\
\hline ALT (U/L) & - & - & $10-710$ & $10-60$ & $0.000^{*}$ \\
\hline GGT (U/L) & - & - & $10-1200$ & $10-150$ & $0.000^{*}$ \\
\hline T. Bil (mg/dl) & - & - & $0.1-8$ & $0.1-0.9$ & $0.000 *$ \\
\hline D. Bil (mg/dl) & - & - & $0.1-4$ & $0.1-0.4$ & $0.000^{*}$ \\
\hline
\end{tabular}

*: Tests with significant difference. WBC: White blood cells; PLT: Platelet; LDH: Lactate dehydrogenase; PTX3: Pentraxin 3; AST: Aspartate aminotransferase; ALT: Alanine aminotransferase; GGT: Gamma glutamyl transferase. SD: Standard deviation; Min.: Minimum; Max.: Maximum.

Table 3. The ratio of patients who developed gallbladder gangrene to the patients without gallbladder gangrene

\begin{tabular}{lccc}
\hline & $\frac{\text { Gangrenous cholecystitis }(\mathbf{n}=8)}{2}$ & & Acute cholecystitis $(\mathbf{n}=18)$ \\
\cline { 2 - 2 } & Mean \pm SD & Mean \pm SD \\
Pentraxin $3(\mathrm{ng} / \mathrm{ml})$ & $25.51 \pm 9.81$ & $26.43 \pm 9.40$ & $>0.05$ \\
\hline
\end{tabular}

\section{DISCUSSION}

Gallbladder disease is one of the common health problems throughout the world. While $40-60 \%$ of people with gallstones manifest an asymptomatic clinical course, in most of the cases with symptomatic cholelithiasis, there is also an asymptomatic period. ${ }^{[5]} 20 \%$ of the patients with symptomatic gallstones are admitted to emergency services with clinical features of acute cholecystitis. Therefore, acute cholecystitis is one of the very common causes of abdominal pain in emergency services. ${ }^{[4]}$

Pentraxins, which are quite stable discoid shaped proteins consisting of structurally cyclic pentamers, are acute phase reactants, playing roles in the early phase of inflammation. There are subgroups in the form of long and short pentraxin. PTX3 belongs to the long pentraxin family and is an inflammatory mediator released particularly by mononuclear phagocytes, dendritic cells, fibroblasts and endothelial cells. [6] PTX3 is considered to be released locally at the actual site of inflammation. ${ }^{[7]}$ Although the plasma levels of PTX3 are very low in normal circumstances $(<2 \mathrm{ng} / \mathrm{ml})$, its plasma concentration increases dramatically and very rapidly, reaching $200-800 \mathrm{ng} / \mathrm{ml}$ in $6-8$ hours. $^{[8]}$ Besides this, platelet aggrega- tion has been shown to be increased correlated with PTX3 released from neutrophils in acute coronary syndrome. ${ }^{[9]}$ Diseases such as sepsis, myocardial infarction and rheumatoid arthritis have been shown to increase plasma PTX3 values. $[8,10,11]$ These findings increase the usability of PTX3 elevation as a harbinger of a probably developing acute episode. In our study, PTX3 levels were significantly higher in the patient group when compared to the control group and helped us in diagnosing this gallbladder infection.

Gallbladder diseases have been reported to be seen more frequently in females than males. ${ }^{[I]}$ While female/male ratio is $4 / 1$ in young age and adults, this ratio decreases with increasing age, because estrogen raises the levels of triglycerides and free fatty acids which are required for the formation of cholesterol stones. Additionally, estrogen stimulates the liver to excrete more cholesterol from blood into bile. Twenty-three (5I\%) patients having gallstones being females in our study supports this information in the literature. In studies conducted on patients having cardiovascular diseases, PTX3 levels have been reported to be lower in females than in males. ${ }^{[12,13]}$ Suliman et al., in their study on patients with chronic renal failure, have reported that PTX3 levels are lower in females than in males. ${ }^{[14]}$ In our study, contrary to the literature, PTX3 levels were 
found higher in subjects with the female gender. However, this result was not statistically significant.

In general surgery clinics, operations related to gallstones and their complications are frequently performed. Gallbladder stones are present in at least 10\% of the adult population. Although being related especially with hereditary and ethnic factors, its prevalence increases with age, and achieves its peak value at $50-60$ years of age. ${ }^{[15]}$ In our study, mean age of patients was 58.7 years, being in accordance with the literature. Abu Seman et al., in their study on patients with type 2 diabetes mellitus who also developed diabetic nephropathy, determined that there was no relationship between age and PTX3. ${ }^{[6]}$ In our study, PTX3 level was found to be increased with increasing age and statistical evaluation revealed that this result was significant.

In acute calculous cholecystitis, white blood cell count increases. Various studies have reported that with values above II.000-20.000/ $\mathrm{mm}^{3}$, complications should be considered. ${ }^{[15]}$ In our study, the average white blood cell count of patients with acute calculous cholecystitis, at their admittance, was $12.900 / \mathrm{mm}^{3}\left(7800 / \mathrm{mm}^{3}-22500 / \mathrm{mm}^{3}\right)$. This result is consistent with the literature. White blood cell count was also found to be statistically significantly high in our study.

Due to its nonspecific physical findings and laboratory results, clinicians experience difficulties in diagnosing gangrenous cholecystitis. Diagnosis is particularly difficult in elderly patients since its classical clinical features are absent. Delayed diagnosis in this population leads to $3.7 \%$ mortality and $40 \%$ morbidity. Since the incidence of cholecystitis is increased in this age group, Nguyen et al. ${ }^{[17]}$ have conducted a study to identify the patients carrying risk factors for gangrenous cholecystitis in which urgent operative intervention is required. They developed an equation in which the components were diabetes mellitus, white blood cell count $=15.000, A L T=50$ $U / L, A L P=200 \mathrm{U} / \mathrm{L}$ and presence of pericholecystic fluid. They determined that the sensitivity was $83 \%$, specificity was $92 \%$, positive predictive value was $71 \%$ and negative predictive value was $96 \%$ for their equation. In some studies performed on ischemic events in patients having myocardial infarction, it has been reported that PTX3 level increases. ${ }^{[17]}$ In our study, increased laboratory values of PTX3 were detected in gangrenous cholecystitis. However, the difference was not statistically significant.

Gallbladder perforation is one of the most serious complications of acute cholecystitis. Perforation occurs after at least three days, generally within the second week following the onset of clinical findings of acute cholecystitis. ${ }^{[4]}$ Stefanidis et al. ${ }^{[18]}$ have reported that gallbladder perforation is seen in $2-15 \%$ of the patients with acute cholecystitis, is not easily distinguishable from acute calculous cholecystitis, is hard to diagnose preoperatively and if not diagnosed early, delayed operative interventions lead to increased morbidity and mor- tality, increased duration of stay in intensive care and hospital. [18] Since we did not have any patients with gallbladder perforation included into our study, we were not able to have an opinion on this subject.

In various studies, the authors have come to the conclusion that elevated PTX3 level is an important parameter in predicting the development of morbidity and mortality in patients with cardiovascular diseases. ${ }^{[19]}$ Mauri et al. ${ }^{[19]}$ have conducted a study showing that elevated PTX3 level is useful in predicting cases with severe sepsis and death. Although PTX3 levels were found to be increased in patients who developed morbidity and mortality, this result was not statistically significant in our study. This might have originated from the small number of the cases who developed morbidity and mortality in our study. In the literature, there is no performed study in relation to PTX3 to the duration of hospitalization. In our study, we determined that patients with high PTX3 levels stayed in the hospital for longer periods than patients with low PTX3 levels. This result was statistically significant. This longer duration was related to delay in achieving their general good state regarding patients with ongoing inflammation (in these patients, PTX levels are high).

\section{Conclusion}

Gallbladder disease is one of the common health problems throughout the world. Although an episode of acute cholecystitis can be diagnosed by physical examination, it is hard to diagnose its complications.

PTX3 levels in our study were statistically significant in terms of elderly patients and increased duration of hospital stay. Additionally, when compared to the control group, PTX3 levels were increased in patients with the female gender, in gangrenous cholecystitis, in patients having morbidity and mortality; however, these results were determined to be statistically insignificant. PTX3 level may be a valuable indicator in diagnosing acute cholecystitis and in predicting prognosis.

\section{Conflict of interest: None declared.}

\section{REFERENCES}

1. Karadeniz E, Ozogul B, Yildırgan MI, Kisaoglu A,Atamanalp SS. Determination of eligibility for laparascopic cholecystectomy of elective patients which decided to indication for surgery. J Exp Clin Med 2013;30:331-4. CrossRef

2. Barie PS, Fischer E. Acute acalculous cholecystitis. J Am Coll Surg 1995;180:232-44.

3. Emsley J, White HE, O'Hara BP, Oliva G, Srinivasan N, Tickle IJ, et al. Structure of pentameric human serum amyloid P component. Nature 1994;367:338-45. CrossRef

4. Introna M, Alles VV, Castellano M, Picardi G, De Gioia L, Bottazzai B, et al. Cloning of mouse ptx3, a new member of the pentraxin gene family expressed at extrahepatic sites. Blood 1996;87:1862-72.

5. Angelico F, Del Ben M, Barbato A, Conti R, Urbinati G. Ten-year in- 
cidence and natural history of gallstone disease in a rural population of women in central Italy. The Rome Group for the Epidemiology and Prevention of Cholelithiasis (GREPCO). Ital J Gastroenterol Hepatol 1997;29:249-54.

6. Bottazzi B, Doni A, Garlanda C, Mantovani A. An integrated view of humoral innate immunity: pentraxins as a paradigm. Annu Rev Immunol 2010;28:157-83. CrossRef

7. Mantovani A, Garlanda C, Bottazzi B, Peri G, Doni A, Martinez de la Torre Y, et al. The long pentraxin PTX3 in vascular pathology. Vascul Pharmacol 2006;45:326-30. CrossRef

8. Muller B, Peri G, Doni A, Torri V, Landmann R, Bottazzi B, et al. Circulating levels of the long pentraxin PTX3 correlate with severity of infection in critically ill patients. Crit Care Med. 2001;29:1404-7. CrossRef

9. Maugeri N, Rovere-Querini P, Slavich M, Coppi G, Doni A, Bottazzi B, et al. Early and transient release of leukocyte pentraxin 3 during acute myocardial infarction. J Immunol 2011;187:970-9. CrossRef

10. Peri G, Introna M, Corradi D, Iacuitti G, Signorini S, Avanzini F, et al. PTX3, A prototypical long pentraxin, is an early indicator of acute myocardial infarction in humans. Circulation 2000;102:636-41. CrossRef

11. Luchetti MM, Piccinini G, Mantovani A, Peri G, Matteucci C, Pomponio $\mathrm{G}$, et al. Expression and production of the long pentraxin PTX3 in rheumatoid arthritis (RA). Clin Exp Immunol 2000;119:196-202. CrossRef

12. Inoue K, Kodama T, Daida H. Pentraxin 3: a novel biomarker for inflam- matory cardiovascular disease. Int J Vasc Med 2012;2012:657025. CrossRef

13. Jenny NS, Arnold AM, Kuller LH, Tracy RP, Psaty BM. Associations of pentraxin 3 with cardiovascular disease and all-cause death: the Cardiovascular Health Study. Arterioscler Thromb Vasc Biol 2009;29:594-9.

14. Suliman ME, Yilmaz MI, Carrero JJ, Qureshi AR, Saglam M, Ipcioglu OM, et al. Novel links between the long pentraxin 3, endothelial dysfunction, and albuminuria in early and advanced chronic kidney disease. Clin J Am Soc Nephrol 2008;3:976-85. CrossRef

15. Lowenfels AB, Velema JP. Estimating gallstone incidence from prevalence data. Scand J Gastroenterol 1992;27:984-6. CrossRef

16. Abu Seman N, Witasp A, Wan Mohamud WN, Anderstam B, Brismar $\mathrm{K}$, Stenvinkel P, et al. Evaluation of the association of plasma pentraxin 3 levels with type 2 diabetes and diabetic nephropathy in a Malay population. J Diabetes Res 2013;2013:298019. CrossRef

17. Nguyen L, Fagan SP, Lee TC, Aoki N, Itani KM, Berger DH, et al. Use of a predictive equation for diagnosis of acute gangrenous cholecystitis. Am J Surg 2004;188:463-6. CrossRef

18. Stefanidis D, Sirinek KR, Bingener J. Gallbladder perforation: risk factors and outcome. J Surg Res 2006;131:204-8. CrossRef

19. Mauri T, Bellani G, Patroniti N, Coppadoro A, Peri G, Cuccovillo I, et al. Persisting high levels of plasma pentraxin 3 over the first days after severe sepsis and septic shock onset are associated with mortality. Intensive Care Med 2010;36:621-9. CrossRef

\section{ORIJINAL ÇALIŞMA - ÖZET}

\section{Akut kolesistitte pentraxin 3 düzeyinin prognostik önemi \\ Dr. Nurhak Aksungur, ${ }^{1}$ Dr. Bünyami Özoğul, ${ }^{1}$ Dr. Nurunnisa Öztürk, ${ }^{2}$ Dr. Şükrü Arslan, ${ }^{1}$ Dr. Erdem Karadeniz, ${ }^{1}$ Dr. Ercan Korkut, ${ }^{1}$ Dr. Mehmet Ali Gül, ${ }^{2}$ Dr. Abdullah Kısaoğlu, ${ }^{1}$ Dr. Sabri Selçuk Atamanalp ${ }^{1}$}

${ }^{1}$ Atatürk Üniversitesi Tıp Fakültesi, Genel Cerrahi Anabilim Dalı, Erzurum

${ }^{2}$ Atatürk Üniversitesi Tıp Fakültesi, Biyokimya Anabilim Dalı, Erzurum

AMAÇ: Safra taşı hastalığı gelişmiş ülkelerde sık görülen bir sorundur. Erişkinlerin en az \% I0'unda safra taşı vardır. Safra taşı olan insanların \%40-60'ı semptomsuz klinik seyir gösterirken, semptomlu kolelitiazisi olan olguların çoğunda da semptomsuz bir dönem bulunur. Semptomlu safra taşlarının \%20'si akut kolesistit tablosu ile acil servislere başvurur. Bu çalışmada, akut kolesistitli olgularda, pentraksin 3 (PTX3) düzeylerin komplikasyonlar ve prognoz üzerindeki tanısal değerini belirlemeyi ve akut kolesistit olgularında morbidite ve mortalite oranlarını azaltmayı amaçladık.

GEREÇ VE YÖNTEM: Bu çalışma Atatürk Üniversitesi Tıp Fakültesi Genel Cerrahi Servisi'nde Eylül 20I2-Ocak 20।4 tarihleri arasında akut taşIı kolesistit tanısı konulup ameliyat edilen hastalar üzerinde yapıldı. Çalışmaya yaşları I ''den büyük, klinik ve radyolojik olarak akut taşlı kolesistit tanısı konmuş 45 hasta (Grup I) ve I 8 yaşüstü 45 sağıklı (Grup II) kişi alındı. Olgular randomize olarak seçildi.

BULGULAR: Çalışmamızda plazma PTX3 düzeyinin hasta grubunda ve morbidite gelişen hastalarda yüksek olmakla birlikte istatisitiksel olarak anlamlı değildi. Pentraksin 3 değerlerinin ileri yaş hastalarda anlamlı olarak arttığı saptandı $(p<0.05)$. Ayrıca hastanede yatış süreli karşılaştııılığında PTX3'ün hastanede daha uzun süre yatan hastalarda daha yüksek olduğu belirlendi $(p<0.05)$.

TARTIŞMA: Pentraksin 3 düzeyleri akut kolesistitli hastalarda değerlendirilen tüm parametrelerde yüksek bulundu. Bu yüzden PTX3 düzeyleri akut kolesistitte tanı ve prognoz tahmininde değerli bir gösterge olabilir.

Anahtar sözcükler: Akut kolesistit; morbidite; mortalite; pentraxin 3.

Ulus Travma Acil Cerrahi Derg 20I5;2I (5):380-384 doi: I0.5505/tjtes.20I5.38839 